Article

\title{
Revisiting the Karyotype Evolution of Neotropical Boid Snakes: A Puzzle Mediated by Chromosomal Fissions
}

\author{
Patrik F. Viana ${ }^{1}(\mathbb{D})$, Tariq Ezaz ${ }^{2}\left(\mathbb{D}\right.$, Marcelo de Bello Cioffi ${ }^{3}(\mathbb{D})$, Thomas Liehr ${ }^{4, *(D)}$, \\ Ahmed Al-Rikabi ${ }^{4}$, Rodrigo Tavares-Pinheiro ${ }^{5}$, Luiz Antônio Carlos Bertollo ${ }^{3}$ and \\ Eliana Feldberg ${ }^{1}$
}

1 Laboratory of Animal Genetics, Instituto Nacional de Pesquisas da Amazônia, Coordenação de Biodiversidade, Av. André Araújo 2936, Petrópolis, Manaus 69067-375, AM, Brazil; Patrik.biologia@gmail.com (P.F.V.); feldberg@inpa.gov.br (E.F.)

2 Institute for Applied Ecology, Faculty of Science and Technology, University of Canberra, Canberra 12 2616, ACT, Australia; Tariq.Ezaz@canberra.edu.au

3 Departamento de Genética e Evolução, Universidade Federal de São Carlos, São Carlos 13565-090, SP, Brazil; mbcioffi@ufscar.br (M.d.B.C.); bertollo@ufscar.br (L.A.C.B.)

4 Institute of Human Genetics, University Hospital Jena, Am Klinikum 1, 07747 Jena, Germany; ahmedgenetic@hotmail.com

5 Departamento de Ciências Biológicas e da Saúde, Laboratório de Herpetologia, Universidade Federal do Amapá, Macapá 68903-419, AP, Brazil; rodrigotmcp@gmail.com

* Correspondence: Thomas.liehr@med.uni-jena.de; Tel.: +49-3641-9396850

Received: 17 September 2020; Accepted: 9 October 2020; Published: 10 October 2020

\begin{abstract}
The Boidae family is an ancient group of snakes widely distributed across the Neotropical region, where several biogeographic events contributed towards shaping their evolution and diversification. Most species of this family have a diploid number composed of $2 n=36$; however, among Booidea families, the Boidae stands out by presenting the greatest chromosomal diversity, with $2 \mathrm{n}$ ranging between 36 and 44 chromosomes and an undifferentiated XY sex chromosome system. Here, we applied a comparative chromosome analysis using cross-species chromosome paintings in five species representing four Boidae genera, to decipher the evolutionary dynamics of some chromosomes in these Neotropical snakes. Our study included all diploid numbers $(2 n=36$, 40 , and 44) known for this family and our comparative chromosomal mappings point to a strong evolutionary relationship among the genera Boa, Corallus, Eunectes, and Epicrates. The results also allowed us to propose the cytogenomic diversification that had occurred in this family: a process mediated by centric fissions, including fission events of the putative and undifferentiated XY sex chromosome system in the $2 \mathrm{n}=44$ karyotype, which is critical in solving the puzzle of the karyotype evolution of boid snakes.
\end{abstract}

Keywords: chromosomal painting; evolution; neotropical region; Serpentes; Booidea

\section{Introduction}

The modern boas (Booidea) and pythons (Pythonoidea) are an ancient group of snakes, often referred to as primitive snakes (Henophidia). Currently, comprising more than 220 valid species, the former diversified lineages of snakes, jointly with Scolecophidia and Caenophidia, represent the three main groups that make up the Serpentes suborder [1-4]. The Booidea superfamily is a monophyletic group [5,6], including six families, Calabariidae, Candoiidae, Sanziniidae, Charinidae, Erycidae, and Boidae, with over 66 species that are distinct both morphologically and 
biogeographically $[5,7,8]$. Calabariidae is restricted to West Africa, whereas Candoiidae is restricted to the Australasian countries, Sanziniidae to Madagascar, Charinidae to Central and North Americas (excepting for a single Colombian species), Erycidae to Europe, Middle East, North Africa, and Central and Southern Asia, and Boidae to the Neotropical region (Figure 1) [4-6,9]. This worldwide distribution is the result of numerous biogeographic events associated with the Gondwana fragmentation [10-14].

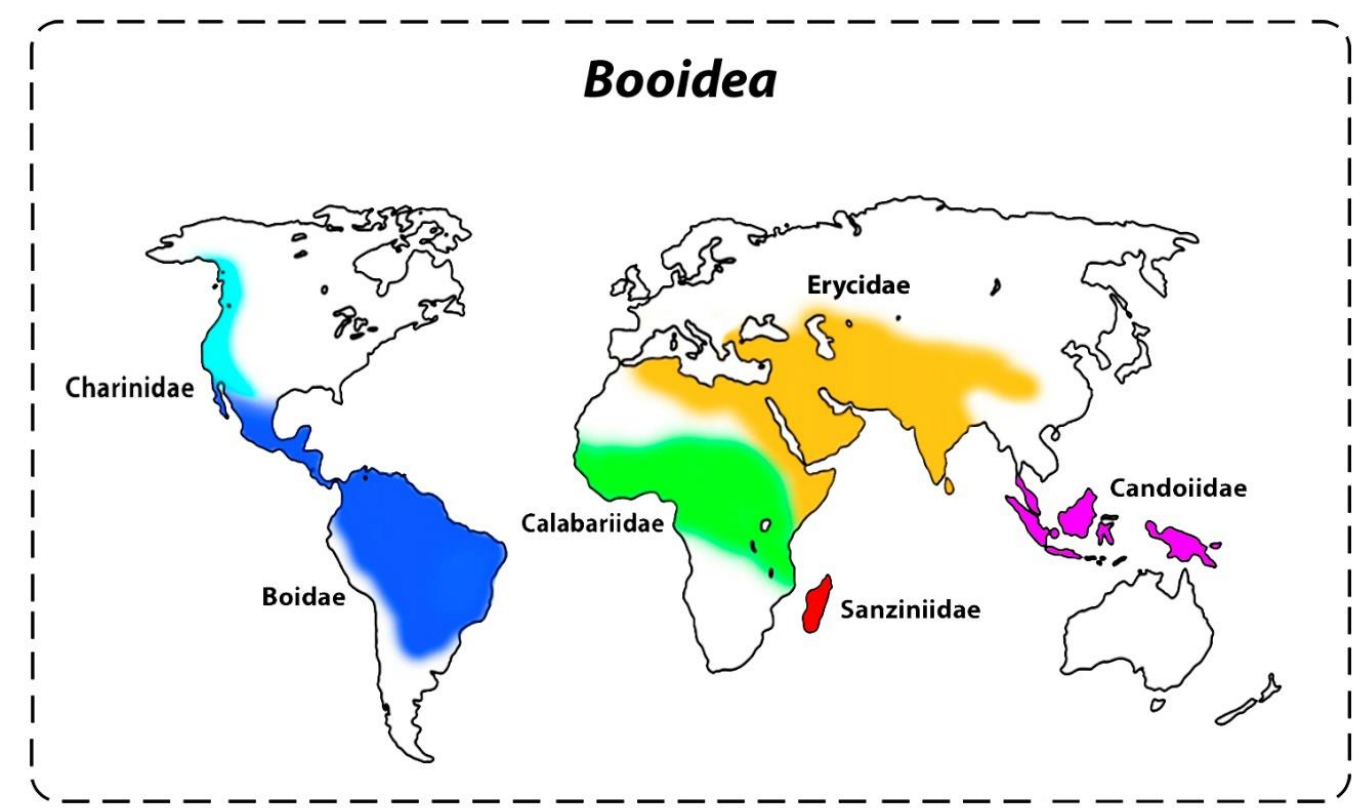

Figure 1. Estimated worldwide distribution pattern of Booidea species according to Reynolds and Henderson [14] and Uetz and Hosek [4].

The Neotropical Boidae family stands out as an intriguing group due to its stunning and complex evolutionary and biogeographic history dating from the end of the Cretaceous period $[12,13,15,16]$. Boids are viviparous species inhabiting a wide range of environments and microhabitats, including different forest landscapes that reflect their varied behaviors, such as generalist (Boa and Epicrates), aquatic (Eunectes), and arboreal (Corallus and Chilabothrus) $[9,17,18]$. Part of the diversification of these snakes was also mediated by vicariant events (e.g., marine incursions, uplift of the Andes, and geology of the Isthmus of Panama) [6,16,19-21]. Boidae is also the most speciose group inside the Booidea superfamily, comprising more than 30 species allocated in five genera, Boa, Corallus, Eunectes, Epicrates, and Chilabothrus [4-6], representing the Neotropical radiation from this superfamily $[5,9,15]$. These snakes differ in biogeographic, morphological, molecular, and even chromosomal characteristics [5,6,22-24].

Most of the Serpentes lineages have $2 n=36$ chromosomes ( 16 macro +20 microchromosomes), which is considered a plesiomorphic feature for the suborder [25-28]. However, Boidae differs from other families by presenting the greatest chromosomal diversity among the Booidea families, with $2 \mathrm{n}$ ranging from 36 to 44 chromosomes, including an undifferentiated $\mathrm{XY}$ sex chromosome system $[24,25,29]$. Robertsonian and non-Robertsonian rearrangements, including fission events [26], have often been proposed to explain this karyotype diversity. Furthermore, the occurrence of interstitial telomeric sequences (ITSs) in most of the analyzed species strongly suggests that multiple chromosomal rearrangements contributed to such diversity $[24,30]$.

Almost six decades ago, the first steps towards understanding the cytotaxonomy of the Neotropical snakes were taken by Professor Willy Beçak, a Brazilian pioneer researcher trying to unravel their chromosome evolution. Beçak discovered a remarkable karyotype diversity for Neotropical Boidae snakes, finding $2 \mathrm{n}=36$ chromosomes for three genera (Boa, Eunectes, and Epicrates) and $2 \mathrm{n}=44$ chromosomes in the Corallus caninus species, whose karyotype was composed only of subtelo/acrocentric like chromosomes. However, the lack of refined taxonomic/molecular tools at the time led Beçak to 
conclude that $2 n=44$ could represent the plesiomorphic condition for the Boidae family and that $2 n=36$ would be a derived condition originating from chromosomal fusions.

Years later, Gorman and Gress [26] added another key piece to this puzzle, by identifying the $2 n=40$ for the species Corallus grenadensis from the West Indies, an intermediate $2 n$ between the 36 as found in Boa, Eunectes, Epicrates, and Chilabothrus and 44, present in Corallus caninus. This intermediate $2 n$ configuration led Gorman and Gress [26] to suggest that the evolution of these snakes had been driven by chromosomal fissions instead of fusions, as previously proposed by Beçak [25], especially because the genus Chilabothrus (with $2 \mathrm{n}=36$ and nominally considered Epicrates at the time) was suggested as an older lineage than Corallus. However, the interpretation that fission events mediated the karyotype evolution of boid snakes was due to a sum of coincidences, since Chilabothrus species, although possessing $2 \mathrm{n}=36$, are not the older lineages in the Boidae family [5,6], but instead Boa, which also has $2 \mathrm{n}=36$ chromosomes.

Given both scenarios of karyotype evolution proposed for neotropical boids, we carried out a cross-species chromosomal investigation performing chromosomal paintings in karyotypes of different Boidae species to decipher events of chromosome rearrangements associated with the evolutionary processes and diversification of this group. Cross-species chromosomal painting is a valuable comparative genomic tool in accessing and deciphering the dynamics of karyotype and genome evolution [31-33]. In this way, we used representative species of the genera Boa, Corallus, Eunectes, and Epicrates, covering all diploid numbers $(2 n=36,40$ and 44$)$ known for the family. Analysis of our data enabled us to estimate the ancestral diploid number for the family, allowing us to shed light on the puzzle of the evolution of Boidae karyotypes.

\section{Material and Methods}

\subsection{Sampling and Mitotic Chromosome Preparation}

Adult snakes were collected from natural populations across the Amazon region under permission granted by Instituto Chico Mendes de Conservação da Biodiversidade (ICMBio), number: 45275 . Chromosomes of Boa constrictor ( $4 o^{\top}$ and $4 \% ; 2 n=36$ ) (Amazonian red-tailed boa), Corallus hortulana $\left(2 \sigma^{\top}\right.$ and $\left.2 \rho ; 2 n=40\right)$ (Amazon tree boa), Corallus caninus $\left(2 o^{\top}\right.$ and $\left.2 \rho ; 2 n=44\right)$ (Negro basin emerald tree boa), Eunectes deschauenseei ( $2 \sigma^{\top}$ and $3 \% ; 2 n=36$ ) (Dark-spotted anaconda), and Epicrates maurus $\left(3 \mathrm{o}^{7}\right.$ and $2 \mathrm{q} ; 2 \mathrm{n}=36$ ) (North rainbow boa) were obtained from small blood samples cultured for 4 days at $29^{\circ} \mathrm{C}$, following the protocol detailed by Viana et al. [34]. gDNA from each individual was extracted from blood using the Wizard Genomic Purification Kit (Promega), according to the manufacturer's recommendations. It is highlighted that no animals were euthanized in this study. All procedures and experimental protocols in this study were approved, performed in accordance with all relevant guidelines and regulations, and fulfill the rules of the Ethics Committee of the National Institute of Amazonian Research (permission number: 018/2017).

\subsection{Microdissection and Chromosome Painting Probe Preparation}

Fifteen copies of the first four chromosome pairs $(1 \mathrm{~m}, 2 \mathrm{sm}, 3 \mathrm{~m}$, and $4 \mathrm{~m})$ of Boa constrictor were isolated via microdissection and amplified following Yang et al. [35]. The whole chromosome-derived probes (designated as Bc1, Bc2, Bc3, and Bc4) were labeled with Spectrum Orange-dUTP or Spectrum Green-dUTP (Vysis, Downers Grove, IL, USA) through 30 cycles of secondary DOP PCR, using $1 \mu \mathrm{L}$ of the primary amplification product as a template DNA, resulting in a final volume of $20 \mu \mathrm{L}$ [35]. The final probe cocktail for each slide was composed of $500 \mathrm{ng}$ of the probes and $60 \mu \mathrm{g}$ of Cot-1 DNA isolated from the Boa constrictor total genomic DNA (for details, see Zwick et al. [36]), to outcompete the hybridization of highly-repeated DNA sequences. However, experiments conducted without Cot-1 DNA as a competitor produced the same results. Hybridization procedure followed our previous studies [37-40] and was performed for 1 day $(24 \mathrm{~h})$ in Boa constrictor and 3 days (72 h) for all the other 
species, at $37^{\circ} \mathrm{C}$ in a dark and moist chamber. After washing procedures, the chromosomes were counterstained with DAPI $(1.2 \mu \mathrm{g} / \mathrm{mL})$ and mounted in antifade solution (Vector).

\subsection{Microscopy and Image Analyses}

At least 10 metaphase spreads per individual, for each probe, were analyzed to confirm the karyotype structure and FISH results. Images were captured using an Olympus BX51 microscope (Olympus Corporation, Ishikawa, Japan). Chromosomes were classified as metacentric (m), subtelocentric (st), or acrocentric (a), according to their arm ratios [41].

\section{Results}

The Amazonian red-tailed boa (Boa constrictor), the dark-spotted anaconda (Eunectes deschauenseei) and the North rainbow boa (Epicrates maurus) have $2 \mathrm{n}=36$ chromosomes (16 macro + 20 microchromosomes), similar to other karyotyped Boa, Eunectes, and Epicrates species [24]. These three species also share full chromosomal homologies with the $\mathrm{Bc} 1, \mathrm{Bc} 2, \mathrm{Bc} 3$, and $\mathrm{Bc} 4$ probes (Figure 2), evidencing synteny among their karyotypes.

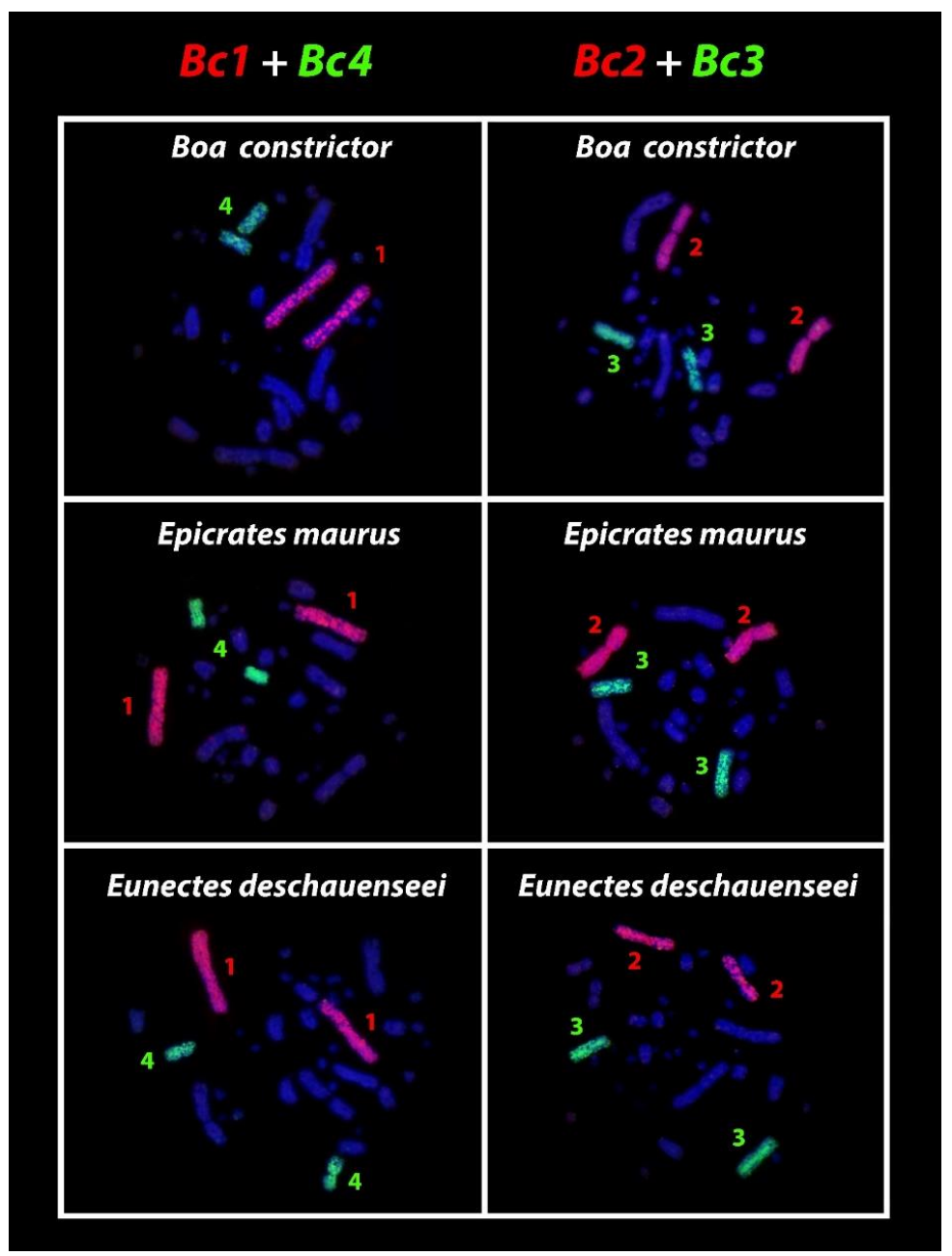

Figure 2. Whole chromosome painting using the $\mathrm{Bc} 1, \mathrm{Bc} 2, \mathrm{Bc} 3$, and $\mathrm{Bc} 4$ Boa constrictor derived probes in chromosomal backgrounds of Boa constrictor $(2 \mathrm{n}=36)$, Epicrates maurus $(2 \mathrm{n}=36)$, and Eunectes deschauenseei $(2 \mathrm{n}=36)$. Note the full homologies of the four chromosome pairs in all of these species. Because the hybridization patterns for males and females were exactly the same, we selected representative metaphase to illustrate the results. 
Corallus hortulana from Central Amazonia (Amazon tree boa) has $2 \mathrm{n}=40$ chromosomes $(4 \mathrm{~m}+16 \mathrm{st} / \mathrm{a}+20$ microchromosomes), corroborating previously published data [24]. This species differs from the other Boidae by having a smaller number of metacentric chromosomes and a greater number of subtelo/acrocentric ones [24]. Bc1 corresponds to chromosome pairs 2 and 4 (st/a) and Bc2 to pairs 3 and 9 (st/a), while Bc3 and Bc4 are found intact as metacentric chromosome pairs 1 and 5 , respectively (Figure 3).

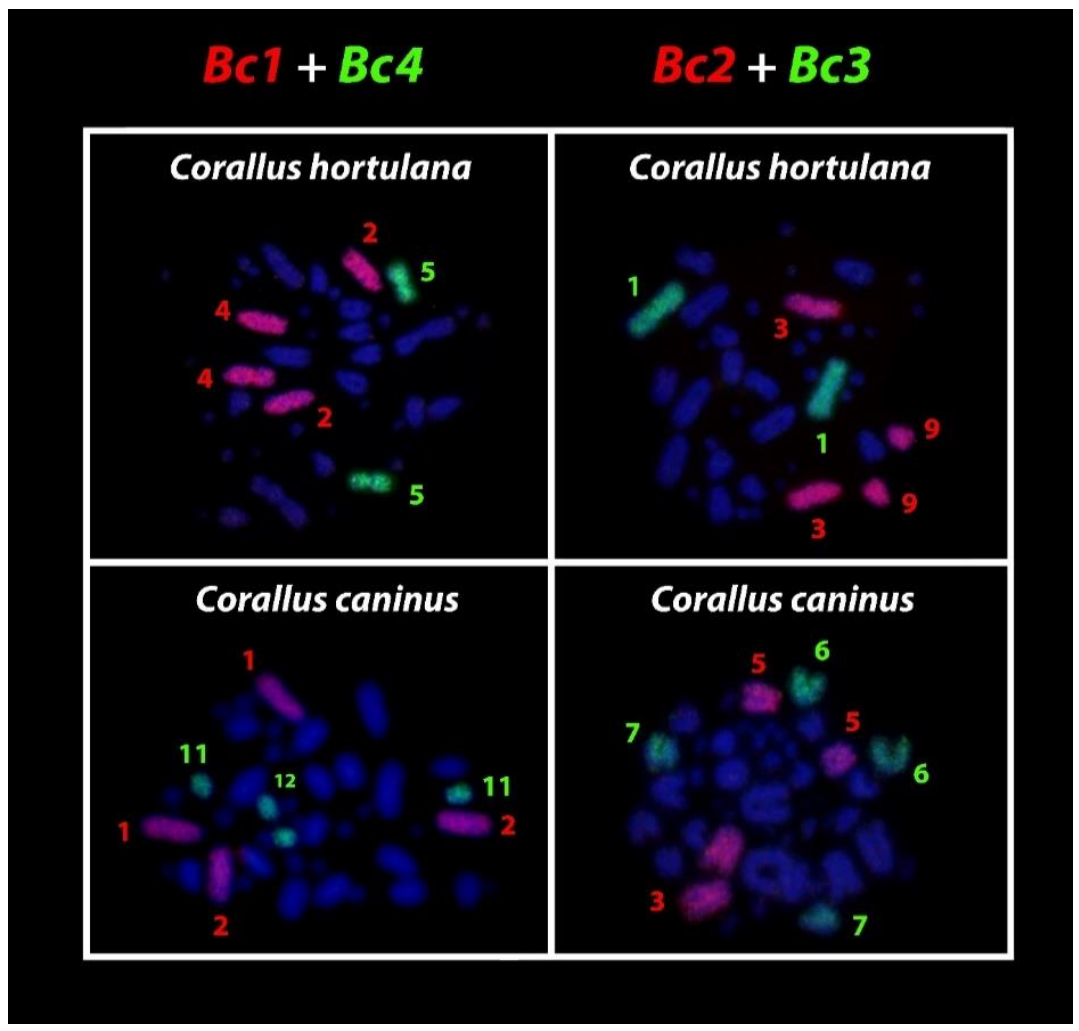

Figure 3. Chromosomal painting using the $\mathrm{Bc} 1, \mathrm{Bc} 2, \mathrm{Bc} 3$, and $\mathrm{Bc} 4$ Boa constrictor $(2 \mathrm{n}=36)$ derived probes in the chromosomal backgrounds of Corallus hortulana $(2 n=40)$ and Corallus caninus $(2 n=44)$. Note that despite their divergent diploid numbers, both species still share chromosome homologies with the oldest genus $(\mathrm{Boa})$ of the Boidae family. Likewise, because the hybridization patterns for males and females were the same, we also selected representative metaphase to illustrate the results.

Corallus caninus has $2 \mathrm{n}=44$ chromosomes, 24 macrochromosomes predominantly subtelo/acrocentrics, and 20 microchromosomes, similar to the pattern described by Beçak [42]. Similar to the Amazon tree boa, C. caninus also shares chromosomal homologies with Bc1, Bc2, Bc3, and Bc4 Boa constrictor pairs. Bc1 corresponds to the chromosome pairs 1 and 2, Bc2 to pairs 3 and 5 , $\mathrm{Bc} 3$ to pairs 6 and 7, and Bc4 to pairs 11 and 12 (Figure 3). We highlight that there were no differences among individuals or between males and females in the patterns observed within all species.

\section{Discussion}

During the past few decades, several studies have attempted to unravel the evolutionary patterns of diversification and phylogenetic relationships of the Neotropical boid lineages [6,12,16], despite an evident cryptic genetic and morphological diversity present in this ancient snake group $[22,23,43,44]$. Today, these animals possess relatively well-resolved phylogenetic relationships, recovering Boa constrictor (i.e., the oldest lineage of the Boidae family) as the sister group of the clade composed of Corallus, Eunectes, Epicrates, and Chilabothrus genera [5,6,12,16,45]. 
Currently, three diploid numbers are known for Boid snakes, 36, 40, and 44, and our comparative chromosomal mappings point to a strong evolutionary relationship among the genera Boa, Corallus, Eunectes, and Epicrates. The chromosome pairs 1, 2, 3, and 4 of Boa constrictor $(2 \mathrm{n}=36)$ are the same as observed in the Eunectes and Epicrates genera $(2 n=36)$ (Figure 2). This suggests that this karyotype configuration $(2 n=36)$ was already present in the most recent common ancestor that gave rise to the genus Boa at the end of the Cretaceous $\sim 75$ mya and retained in Eunectes, Epicrates, and Chilabothrus (Figure 4).

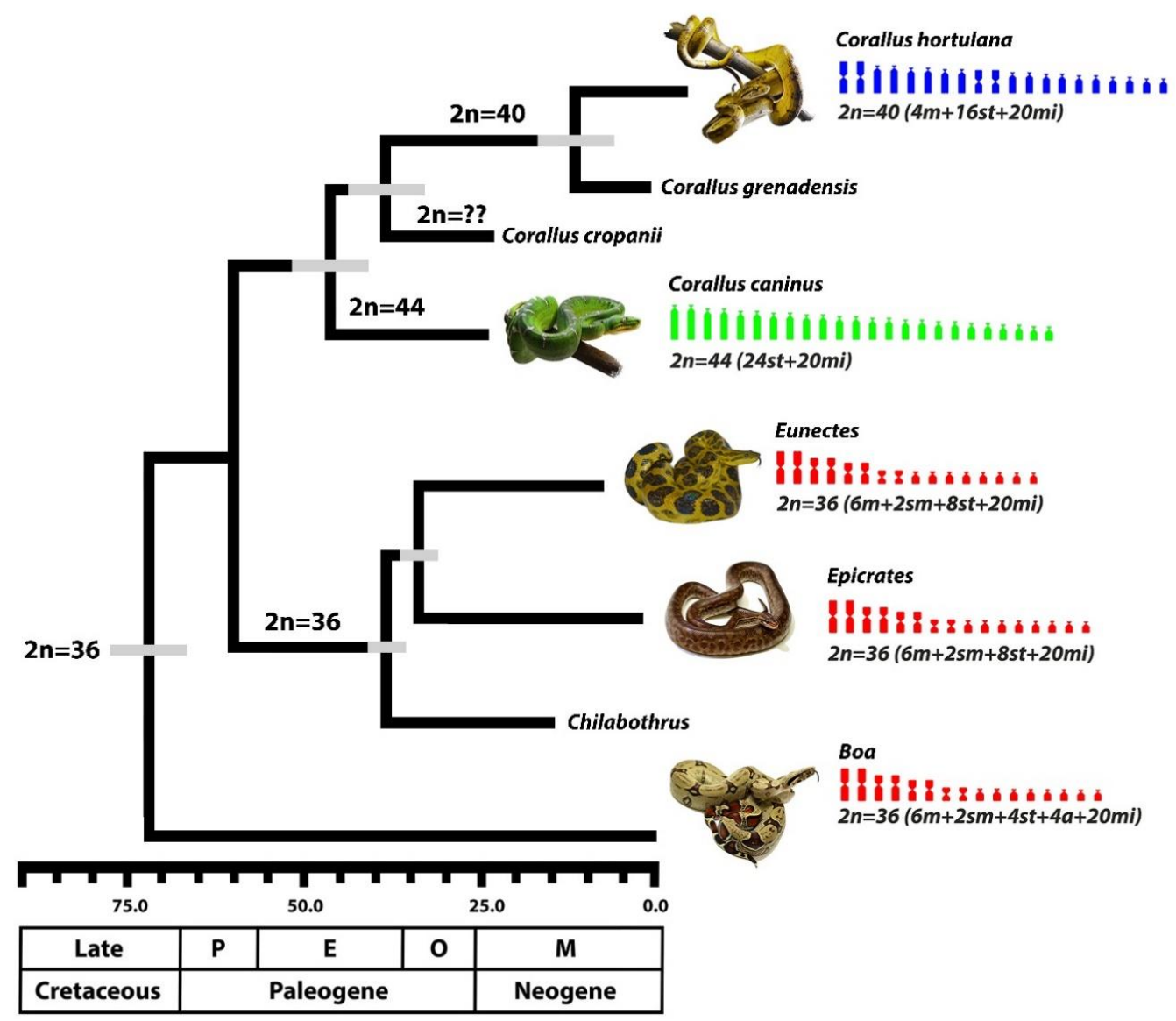

Figure 4. Chronogram of Neotropical boid snakes, adapted from Colston et al. [16]. Only macrochromosomes are illustrated, since all species retain 20 microchromosomes. Highlighted in blue, the $2 \mathrm{n}=40$; green, $2 \mathrm{n}=44$; and in red, the $2 \mathrm{n}=36 . \mathrm{P}=$ Paleocene; $\mathrm{E}=$ Eocene; $\mathrm{O}=$ Oligocene; $\mathrm{M}=$ Miocene. We highlight that the tree proposed by Colston et al. [16] displays the phylogenetic relationships between species and does not represent the current age of the chromosomal rearrangement's events.

However, these chromosome pairs underwent centric fissions and can also be found in independent diversification events spanning $\sim 60$ mya (Paleogene/Neogene), which gave rise to the modern tree boa species of the genus Corallus in the Neotropical region (Figure 4). The sum of the available data indicates that the karyotype diversification of the Corallus genus occurred through chromosomal fissions in the first four pairs of the common ancestral complement for the Boidae family (pairs $1 \mathrm{~m}$, $2 \mathrm{sm}, 3 \mathrm{~m}, 4 \mathrm{~m}$ ), as found in Boa constrictor (Figure 5). However, additional fission/fusion events that may have taken place (e.g., involving the acrocentrics or even microchromosomes) cannot be ruled out. 


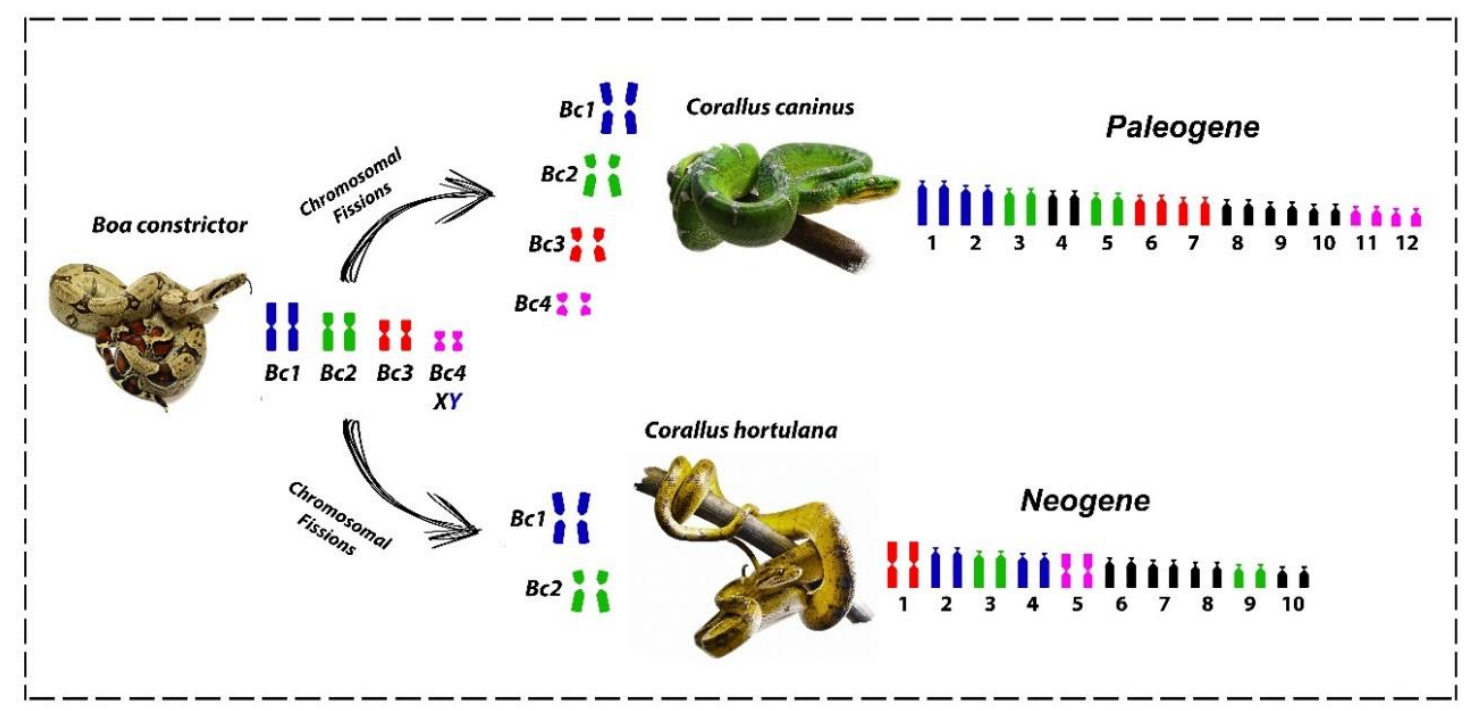

Figure 5. Schematic representation of the macrochromosome diversification in Corallus species mediated by chromosomal fissions. The first four chromosome pairs of Boa constrictor correspond to 8 pairs in Corallus caninus and 6 pairs in Corallus hortulana (highlighted by the colors).

The karyotype diversification in Corallus species, interestingly, did not follow the usual evolutionary trend, from $2 n=36$ to $2 n=40$ to $2 n=44$, as suggested by Gorman and Gress [26]. Indeed, Corallus genus ( $2 \mathrm{n}=40$ and 44$)$ and its sister group, the clade Eunectes, Epicrates, and Chilabothrus (all species with $2 n=36$ ), shared the most recent common ancestor dating back to the early Paleogene (Figure 4 ). The Corallus lineages exhibit two karyotype configurations, the $2 n=40$ and $2 n=44$ chromosomes that arose in the middle of the Paleogene/Eocene from centric fissions in all meta and submetacentric chromosomes (pairs $1 \mathrm{~m}, 2 \mathrm{sm}, 3 \mathrm{~m}$, and $4 \mathrm{~m}$ ), which are present in their most recent common ancestor (Figures 4 and 5). Corallus experienced different evolutionary pressures along with their diversification in the Neotropical region (Figure 6), following different evolutionary trajectories, especially if we take into account that the $2 \mathrm{n}=44$ composed only of subtelo/acrocentric chromosomes is exclusively found in Corallus caninus. However, the $2 \mathrm{n}=40$ is retained during the diversification events of the other Neotropical tree boa species, such as the split of the clade composed of Corallus hortulana and Corallus grenadensis, which dates back to recent $\sim 10$ mya in the Neogene (Figure 4). Meanwhile, the ancestral state $2 \mathrm{n}=36$ is retained along the diversification and split among Eunectes, Epicrates, and Chilabothrus genera in the Paleogene/Neogene (Figure 4).

Interestingly, the undifferentiated putative $X Y$ sex chromosomes of Boa constrictor $[29,46]$ remained conserved in species with $2 n=36$ (putative pair 4 in Eunectes and Epicrates) and with $2 n=40$ (pair 5 in Corallus hortulana). On the other hand, in Corallus caninus $(2 n=44)$, the putative XY chromosomes of Boa constrictor underwent fission events, giving rise to the smallest acrocentric chromosomes of the complement, pairs 11 and 12 (Figures 3 and 5). This chromosomal homology of the putative $X Y$ (4th pair), across Boidae lineages, suggests that other genera of the family may also share an undifferentiated $X Y$ system of sex chromosomes, even though Corallus caninus presents the putative Boa XY as four small acrocentric chromosomes (pairs 11 and 12) (Figure 5). Furthermore, consecutive parthenogenetic births in Eunectes, Epicrates and Chilabothrus, producing exclusively females, also support an XY system shared among Boidae species [29,47-49]. In Corallus caninus, the putative Boa XY is homologous to pairs 11 and 12 due to a fission event, however, it is uncertain whether a functional $X Y$ sex chromosome system exists in this lineage or if a multiple $X Y$ system evolved through this fission event. Comparative mappings from the putative Boa XY derived probes in sister lineages, such as the well-differentiated ZW (also the 4th pair) present in Acrantophis [50], will certainly highlight the homologies of sequences as well as turnovers between the sex chromosome systems in these ancient groups of snakes. 

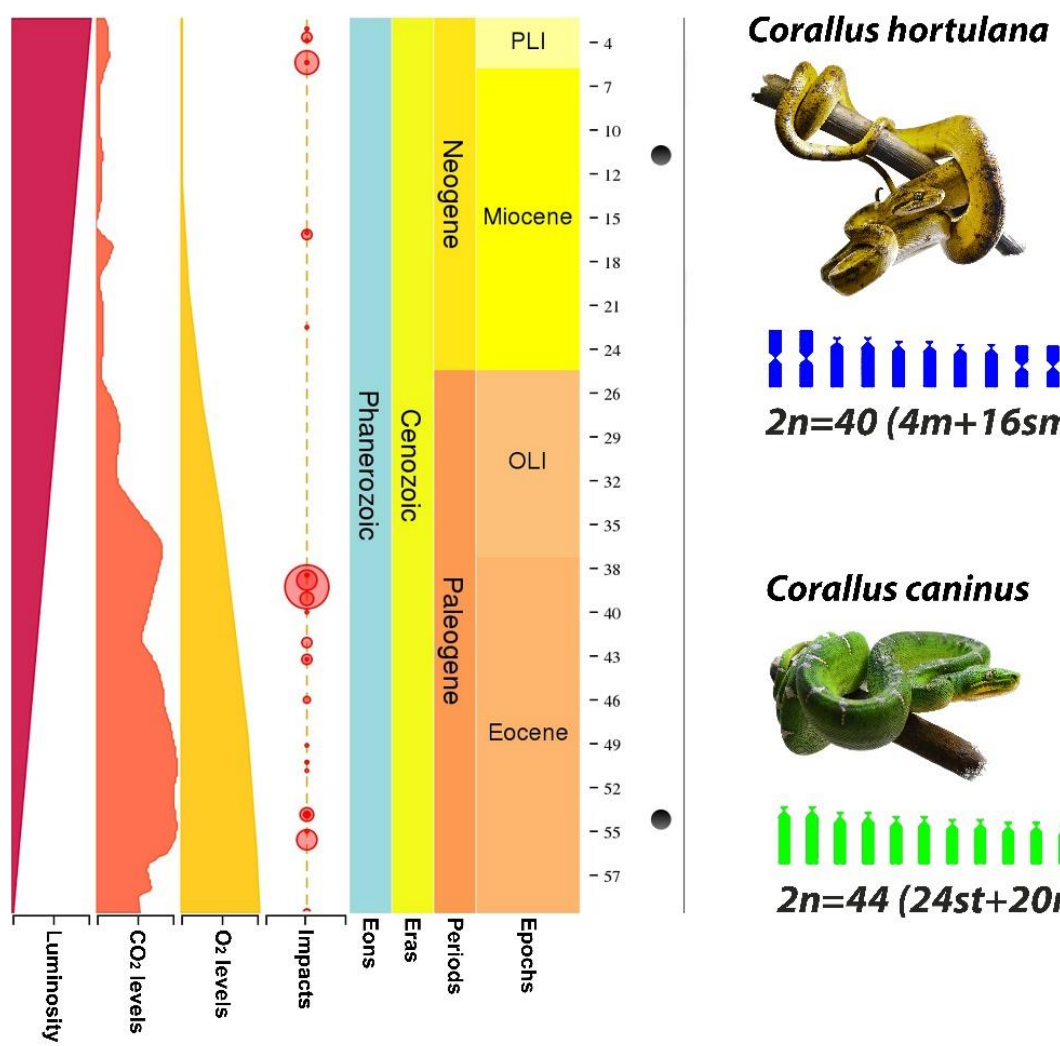

\section{Hilitilinitiminat $2 n=40(4 m+16 s m+20 m i)$}

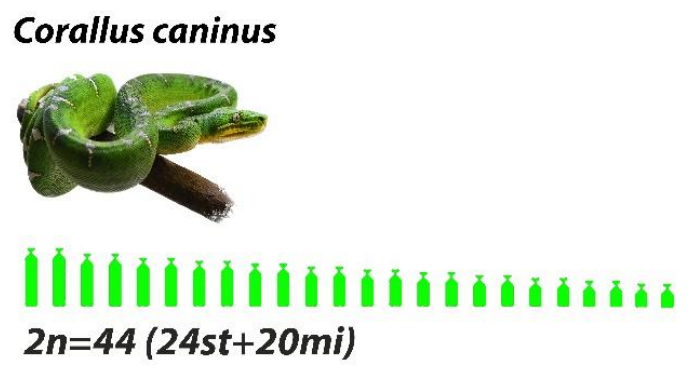

Figure 6. Estimated time of partial divergence between $2 n=40$ (Corallus hortulana-Neogene) and $2 n=44$ (Corallus caninus_-Paleogene), with 45 million years of split and independent evolution on average. Graphics indicate the impacts, $\mathrm{O}_{2}$ levels, $\mathrm{CO}_{2}$ levels, and luminosity conditions on Earth in each geological scale, along with the species diversification in the Neotropical region. The estimated pairwise was retrieved from the TimeTree online database (http://www.timetree.org/).

In conclusion, our study shed light on the puzzle of the karyotype evolution of Neotropical boids. We estimated the likely ancestral karyotype status for the Boidae family and detailed the cytogenomic diversification that had occurred in this family. Particularly, our study highlighted that processes mediated by fissions generated the current karyotype configurations of this Neotropical clade of primitive snakes. This study is part of a series of further cytogenetic and genomic studies focusing on Neotropical reptiles and their hidden evolutionary diversity.

Author Contributions: Designed the study and initial structure, P.F.V.; project administration, P.F.V.; investigation, P.F.V., T.E., M.d.B.C., R.T.-P., L.A.C.B., E.F.; methodology and laboratory experiments, P.F.V., T.E., M.d.B.C., T.L., A.A.-R., R.T.-P. All authors analyzed and interpreted the data. P.F.V. wrote the manuscript, with contributions from all coauthors. All authors have read and agreed to the published version of the manuscript.

Funding: This work was supported by Fundação de Amparo à Pesquisa do Amazonas (FAPEAM), Coordenação de Aperfeiçoamento de Pessoal de Nível Superior (CAPES) (Grant Number: 88881.190036/2018-01), Conselho Nacional de Desenvolvimento Científico e Tecnológico (CNPq) (Grant number: 302449/2018-3), Coordenação de Aperfeiçoamento de Pessoal de Nível Superior CAPES/Alexander von Humboldt (Grant number: 88881.136128/2017-01), Center for Studies on Adaptations of Aquatic Biota of the Amazon (ADAPTA), Projects (Grant Number: Pronex/FAPEAM/CNPq 003/2009), Coordenação de Aperfeiçoamento de Pessoal de Nível Superior CAPES-Pro-Amazon Program: Biodiversity and Sustainability (Grant Number: Public Notice No. 047/2012).

Acknowledgments: We are grateful to Milena Miranda and Leonardo Matos from the Animal Husbandry of the National Institute of Amazonian Research (Biotério Central-INPA); Marcelo Garcia from the Institute of Environmental Protection of Amazonas (IPAAM); Milena and Breno Almeida from the Amazonian Center for Herpetology (Centro Amazônico de Herpetologia); Tiago Lima from the Boas of Brazil breeding (Criatório Jibóias Brasil), and George Myller from the DinoPet Animal breeding (Criatório DinoPet) for all valuable support provided.

Conflicts of Interest: The authors declare no conflict of interest. 


\section{References}

1. Pyron, R.A.; Burbrink, F.T.; Wiens, J.J. A phylogeny and revised classification of Squamata, including 4161 species of lizards and snakes. BMC Evol. Biol. 2013, 13, 1-54. [CrossRef]

2. Hsiang, A.Y.; Field, D.J.; Webster, T.H.; Behlke, A.D.B.; Davis, M.B.; Racicot, R.A.; Gauthier, J. The origin of snakes: Revealing the ecology, behavior, and evolutionary history of early snakes using genomics, phenomics, and the fossil record. BMC Evol. Biol. 2015, 15, 8. [CrossRef]

3. Zheng, Y.; Wiens, J.J. Combining phylogenomic and supermatrix approaches, and a time-calibrated phylogeny for squamate reptiles (lizards and snakes) based on 52 genes and 4162 species. Mol. Phylogenet. Evol. 2016, 94, 537-547. [CrossRef]

4. The Reptile Database. Available online: http://www.reptile-database.org (accessed on 22 May 2020).

5. Pyron, R.A.; Reynolds, R.G.; Burbrink, F.T. A taxonomic revision of boas (Serpentes: Boidae). Zootaxa 2014, 3846, 249-260. [CrossRef]

6. Reynolds, R.G.; Niemiller, M.L.; Revell, L.J. Toward a Tree-of-Life for the boas and pythons: Multilocus species-level phylogeny with unprecedented taxon sampling. Mol. Phylogenet. Evol. 2014, 71, $201-213$. [CrossRef] [PubMed]

7. Underwood, G. A Contribution to the Classification of Snakes, 1st ed.; Trustees of the British Museum (Natural History): London, UK, 1967.

8. Kluge, A.G. Boine snake phylogeny and research cycles. Misc. Publ. Mus. Zool. Univ. Mich. 1991, 178, 1-58.

9. Reed, R.N.; Rodda, G.H. Giant Constrictors: Biological and Management Profiles and an Establishment Risk Assessment for Nine Large Species of Pythons, Anacondas, and the Boa constrictor, Open-File Report 2009-1202; U.S. Geological Survey: Fort Collins, CO, USA, 2009; 302p.

10. Rage, J.-C.; Burg, J.P.; Matte, P.; Leyreloup, A.; Marchand, J. Gondwana, Tethys, and terrestrial vertebrates during the Mesozoic and Cainozoic. Geol. Soc. Lond. Spec. Publ. 1988, 37, 255-273. [CrossRef]

11. Rage, J.C. Fossil snakes from the Paleocene of São José de Itaboraí, Brazil, Part II. Boidae. Palaeovertebrata 2001, 30, 111-150.

12. Noonan, B.P.; Chippindale, P.T. Dispersal and vicariance: The complex evolutionary history of boid snakes. Mol. Phylogenet. Evol. 2006, 40, 347-358. [CrossRef]

13. Noonan, B.P.; Chippindale, P.T. Vicariant origin of Malagasy reptiles supports late cretaceous Antarctic land bridge. Am. Nat. 2006, 168, 730-741. [CrossRef]

14. Reynolds, R.G.; Henderson, R.W. Boas of the World (Superfamily Booidae): A Checklist With Systematic, Taxonomic, and Conservation Assessments. Bull. Mus. Comp. Zool. 2018, 162, 1-58. [CrossRef]

15. Vidal, N.; Dewynter, M.; Gower, D.J. Dissecting the major American snake radiation: A molecular phylogeny of the Dipsadidae Bonaparte (Serpentes, Caenophidia). Comptes Rendus Biol. 2010, 333, 48-55. [CrossRef]

16. Colston, T.J.; Grazziotin, F.G.; Shepard, D.B.; Vitt, L.J.; Colli, G.R.; Henderson, R.W.; Blair Hedges, S.; Bonatto, S.; Zaher, H.; Noonan, B.P.; et al. Molecular systematics and historical biogeography of tree boas (Corallus spp.). Mol. Phylogenet. Evol. 2013, 66, 953-959. [CrossRef] [PubMed]

17. Henderson, R.W.; Micucci, T.W.P.; Puorto, G.; Bourgeois, R.W. Ecological correlates and patterns in the distribution of Neotropical boines (Serpentes: Boidae): A preliminary assessment. Herpetol. Nat. His. 1995, 1, $15-27$.

18. Viana, P.F. Corallus hortulanus (Amazon Tree Boa). Neonate size and timing of reproduction in captivity. Herpetol. Rev. 2017, 48, 87.

19. Vidal, N.; Henderson, R.W.; Delmas, A.S.; Hedges, S.B. A phylogenetic study of the emerald tree boa (Corallus caninus). J. Herpetol. 2005, 39, 500-503. [CrossRef]

20. Hoorn, C.; Wesselingh, F.P. Introduction: Amazonia, landscape and species evolution. In Amazonia: Landscape and Species Evolution: A Look into the Past, 1st ed.; Hoorn, C., Wesselingh, F.P., Eds.; Wiley: New York, NY, USA, 2010; Volume 1, pp. 1-6.

21. Hoorn, C.; Wesselingh, F.P.; Ter Steege, H.; Bermúdez, M.; Mora, A.; Sevink, J.; Sanmartin, I.; Sanchez-Meseguer, A.; Anderson, C.L.; Figueiredo, J.P.; et al. Amazonia Through Time: Andean Uplift, Climate Change, Landscape Evolution, and Biodiversity. Science 2010, 330, 927-9311. [CrossRef]

22. Henderson, R.W.; Powell, R. Natural History of West Indian Reptiles and Amphibians, 1st ed.; University Press of Florida: Gainesville, FL, USA, 2009. 
23. Card, D.C.; Schield, D.R.; Adams, R.H.; Corbin, A.B.; Perry, B.W.; Andrew, A.L.; Pasquesi, G.I.M.; Smith, E.N.; Jezkova, T.; Boback, S.M.; et al. Phylogeographic and population genetic analyses reveal multiple species of Boa and independent origins of insular dwarfism. Mol. Phylogenet. Evol. 2016, 102, 104-116. [CrossRef]

24. Viana, P.F.; Ribeiro, L.B.; Souza, G.M.; Chalkidis, H.D.M.; Gross, M.C.; Feldberg, E. Is the Karyotype of Neotropical Boid Snakes Really Conserved? Cytotaxonomy, Chromosomal Rearrangements and Karyotype Organization in the Boidae Family. PLoS ONE 2016, 11, e0160274. [CrossRef]

25. Beçak, W.; Beçak, M.L. Cytotaxonomy and chromosomal evolution in Serpentes. Cytogenet. Genome Res. 1969, 8, 247-262. [CrossRef]

26. Gorman, G.C.; Gress, F. Chromosome cytology of four boid snakes and a varanid lizard, with comments on the cytosystematics of primitive snakes. Herpetologica 1970, 26, 308-317.

27. Singh, L. Evolution of karyotypes in snakes. Chromosoma 1972, 38, 185-236. [CrossRef] [PubMed]

28. Viana, P.F.; Ezaz, T.; Cioffi, M.B.; Almeida, B.J.; Feldberg, E. Evolutionary Insights of the ZW Sex Chromosomes in Snakes: A New Chapter Added by the Amazonian Puffing Snakes of the Genus Spilotes. Genes 2019, 10, 288. [CrossRef]

29. Gamble, T.; Castoe, T.A.; Nielsen, S.V.; Banks, J.L.; Card, D.C.; Schield, D.R.; Schuett, G.W.; Booth, W. The Discovery of XY Sex Chromosomes in a Boa and Python. Curr. Biol. 2017, 27, 2148-2153.e4. [CrossRef] [PubMed]

30. Augstenová, B.; Mazzoleni, S.; Kostmann, A.; Altmanová, M.; Frynta, D.; Kratochvíl, L.; Rovatsos, M. Cytogenetic Analysis Did Not Reveal Differentiated Sex Chromosomes in Ten Species of Boas and Pythons (Reptilia: Serpentes). Genes 2019, 10, 934. [CrossRef] [PubMed]

31. Trifonov, V.A.; Paoletti, A.; Barucchi, V.C.; Kalinina, T.; O’Brien, P.C.M.; Ferguson-Smith, M.A.; Giovannotti, M. Comparative Chromosome Painting and NOR Distribution Suggest a Complex Hybrid Origin of Triploid Lepidodactylus lugubris (Gekkonidae). PLoS ONE 2015, 10, e0132380. [CrossRef]

32. Cioffi, M.B.; Ráb, P.; Ezaz, T.; Bertollo, L.; Lavoué, S.; Oliveira, E.A.; Sember, A.; Molina, W.F.; Souza, F.; Majtánová, Z.; et al. Deciphering the evolutionary history of arowana fishes (Teleostei, Osteoglossiformes, Osteoglossidae): Insight from comparative cytogenomics. Int. J. Mol. Sci. 2019, 20, 4296. [CrossRef]

33. Lisachov, A.P.; Giovannotti, M.; Pereira, J.C.; Andreyushkova, D.A.; Romanenko, S.A.; Ferguson-Smith, M.A.; Borodin, P.M.; Trifonov, V.A. Chromosome Painting Does Not Support a Sex Chromosome Turnover in Lacerta agilis Linnaeus, 1758. Cytogenet. Genome Res. 2020, 160, 134-140. [CrossRef]

34. Viana, P.F.; Ribeiro, L.B.; Lima, T.; De Carvalho, V.T.; Vogt, R.C.; Gross, M.C.; Feldberg, E. An optimized protocol for obtaining mitotic chromosomes from cultured reptilian lymphocytes. Nucleus 2016, 59, 191-195. [CrossRef]

35. Yang, F.; Trifonov, V.; Ng, B.L.; Kosyakova, N.; Carter, N.P. Generation of paint probes by flow-sorted and microdissected chromosomes. In Fluorescence In Situ Hybridization (FISH)_Application Guide, 1st ed.; Liehr, T., Ed.; Springer: Berlin/Heidelberg, Germany, 2009; Volume 1, pp. 35-52.

36. Zwick, M.S.; Hanson, R.E.; Islam-Faridi, M.N.; Stelly, D.M.; Wing, R.A.; Price, H.J.; McKnight, T.D. A rapid procedure for the isolation of C0t-1 DNA from plants. Genome 1997, 40, 138-142. [CrossRef]

37. Viana, P.F.; Feldberg, E.; Cioffi, M.B.; De Carvalho, V.T.; Menezes, S.; Vogt, R.C.; Liehr, T.; Ezaz, T. The Amazonian Red Side-Necked Turtle Rhinemys rufipes (Spix, 1824) (Testudines, Chelidae) Has a GSD Sex-Determining Mechanism with an Ancient XY Sex Microchromosome System. Cells 2020, 9, 2088. [CrossRef] [PubMed]

38. Toma, G.A.; De Moraes, R.L.R.; Sassi, F.D.M.C.; Bertollo, L.A.C.; De Oliveira, E.A.; Rab, P.; Sember, A.; Liehr, T.; Hatanaka, T.; Viana, P.F.; et al. Cytogenetics of the small-sized fish, Copeina guttata (Characiformes, Lebiasinidae): Novel insights into the karyotype differentiation of the family. PLoS ONE 2019, 14, e0226746. [CrossRef] [PubMed]

39. Sassi, F.M.C.; Hatanaka, T.; Moraes, R.L.R.; Toma, G.A.; Oliveira, E.A.; Liehr, T.; Rab, P.; Bertollo, L.A.C.; Viana, P.F.; Feldberg, E.; et al. An insight into the chromosomal evolution of Lebiasinidae (Teleostei, Characiformes). Genes 2020, 11, 365. [CrossRef] [PubMed]

40. Sember, A.; Oliveira, E.A.; Ráb, P.; Bertollo, L.; Freitas, N.L.; Viana, P.F.; Yano, C.F.; Hatanaka, T.; Marinho, M.; de Moraes, R.; et al. Centric Fusions behind the Karyotype Evolution of Neotropical Nannostomus Pencilfishes (Characiforme, Lebiasinidae): First Insights from a Molecular Cytogenetic Perspective. Genes 2020, 11, 91. [CrossRef] [PubMed] 
41. Levan, A.; Fredga, K.; Sandberg, A.A. Nomenclature for centromeric position on chromosomes. Hereditas 1964, 52, 201-220. [CrossRef]

42. Beçak, W. Constituição cromossômica e mecanismo de determinação do sexo em ofídios sul-americanos. I. Aspectos cariotípicos. Mem. Inst. Butantan. 1965, 32, 37-78.

43. Hynková, I.; Starostová, Z.; Frynta, D. Mitochondrial DNA Variation Reveals Recent Evolutionary History of Main Boa constrictor Clades. Zool. Sci. 2009, 26, 623-631. [CrossRef]

44. Suárez-Atilano, M.; Burbrink, F.; Vázquez-Domínguez, E. Phylogeographical structure within Boa constrictor imperator across the lowlands and mountains of Central America and Mexico. J. Biogeogr. 2014, 41, 2371-2384. [CrossRef]

45. Burbrink, F.T. Inferring the phylogenetic position of Boa constrictor among the Boinae. Mol. Phylogenet. Evol. 2005, 34, 167-180. [CrossRef]

46. Viana, P.F.; Ezaz, T.; Cioffi, M.D.B.; Liehr, T.; Al-Rikabi, A.; Goll, L.G.; Rocha, A.M.; Feldberg, E. Landscape of snake' sex chromosomes evolution spanning 85 MYR reveals ancestry of sequences despite distinct evolutionary trajectories. Sci. Rep. 2020, 10, 1-14. [CrossRef]

47. Booth, W.; Million, L.; Reynolds, R.G.; Burghardt, G.M.; Vargo, E.L.; Schal, C.; Tzika, A.C.; Schuett, G.W. Consecutive Virgin Births in the New World Boid Snake, the Colombian Rainbow Boa, Epicrates maurus. J. Hered. 2011, 102, 759-763. [CrossRef] [PubMed]

48. Shibata, H.; Sakata, S.; Hirano, Y.; Nitasaka, E.; Sakabe, A. Facultative parthenogenesis validated by DNA analyses in the green anaconda (Eunectes murinus). PLoS ONE 2017, 12, e0189654. [CrossRef] [PubMed]

49. Seixas, F.; Morinha, F.; Luis, C.; Alvura, N.; dos Anjos Pires, M. DNA-validated parthenogenesis: First case in a captive Cuban boa (Chilabothrus angulifer). bioRxiv 2020, 751529. [CrossRef]

50. Augstenová, B.; Pokorná, M.J.; Altmanová, M.; Frynta, D.; Rovatsos, M.; Kratochvíl, L. ZW, XY, and yet ZW: Sex chromosome evolution in snakes even more complicated. Evolution 2018, 72, 1701-1707. [CrossRef] [PubMed]

(C) 2020 by the authors. Licensee MDPI, Basel, Switzerland. This article is an open access article distributed under the terms and conditions of the Creative Commons Attribution (CC BY) license (http://creativecommons.org/licenses/by/4.0/). 